\title{
Improving sustainability by technology assessment and systems analysis: the case of IWRM Indonesia
}

\author{
S. Nayono ${ }^{1}$ A. Lehmann ${ }^{2} \cdot$ J. Kopfmüller ${ }^{3}$ H. Lehn ${ }^{3}$
}

Received: 20 January 2016/ Accepted: 12 May 2016/Published online: 10 June 2016

(c) The Author(s) 2016. This article is published with open access at Springerlink.com

\begin{abstract}
To support the implementation of the IWRMIndonesia process in a water scarce and sanitation poor region of Central Java (Indonesia), sustainability assessments of several technology options of water supply and sanitation were carried out based on the conceptual framework of the integrative sustainability concept of the German Helmholtz association. In the case of water supply, the assessment was based on the life-cycle analysis and life-cycle-costing approach. In the sanitation sector, the focus was set on developing an analytical tool to improve planning procedures in the area of investigation, which can be applied in general to developing and newly emerging countries. Because sanitation systems in particular can be regarded as socio-technical systems, their permanent operability is closely related to cultural or religious preferences which influence acceptability. Therefore, the design of the tool and the assessment of sanitation technologies took into account the views of relevant stakeholders. The key results of the analyses are presented in this article.
\end{abstract}

Keywords IWRM · Indonesia · Water supply · Sanitation · Technology assessment · Sustainability assessment .

Stakeholder involvement

H. Lehn

helmut.lehn@kit.edu

1 Department of Civil Engineering, Faculty of Engineering, Janabadra University, Yogyakarta, Indonesia

2 Department of Environmental Technology, Technical University Berlin, Berlin, Germany

3 Institute for Technology Assessment and Systems Analysis, KIT, Karlsruhe, Germany

\section{Background and objectives of the work}

To suitably cope with existing severe deficits in fresh water supply and sanitation, and following the Agenda 21 which was adopted at the UN Conference on Environment and Development 1992 in Rio, these issues were addressed in the framework of the United Nations Millennium Development Goals in 2000 (United Nations 2000). Here, the international community of states determined, among others, the target $7 \mathrm{c}$ to "halve, by 2015 , the proportion of the population without sustainable access to safe drinking water and basic sanitation". According to this, the implementation of integrated water resource management (IWRM) projects all over the world, particularly in developing and newly emerging countries, has been promoted. Currently, the IWRM approach represents the main guiding principle in the water sector. According to the widely accepted definition of the Global Water Partnership, "IWRM is a process which promotes the co-ordinated development and management of water, land, and related resources, to maximize the resultant economic and social welfare in an equitable manner without compromising the sustainability of vital ecosystems" (GWP 2000).

Since water is a critical, but often neglected element to achieve global sustainable development, improved water management strategies are highly necessary. Basically, IWRM was developed as a cross-sectoral approach, designed to replace traditional, mostly fragmented sectoral approaches which dominated the water sector by then and imposed high economic, social, and ecological costs on human societies and the natural environment. In this sense, "integrated management" is understood and should be implemented in four main respects: (1) by considering ecological, economic, social, as well as institutional and cultural aspects and their interlinkages; (2) by addressing 
the interdependencies between water-as a natural, social, and economic good-and land and other natural resources; (3) by taking into consideration, the different usages of water-for drinking, food production, industries, or ecosystems functioning-which may lead to conflicting uses under certain conditions; (4) by considering a key element of the sustainability model, participatory and transdisciplinary approaches are an additional request for integration, by ensuring that management and decision making takes into account the needs and preferences of different users and stakeholders suitably (US AfID 2003).

Like other basic supply infrastructure systems, such as energy, transportation, etc., the freshwater-/wastewater system is a socio-technical system. This means that both, its functioning and transformation, are influenced not only by technical and economic factors, but similarly by societal and individual values and preferences, by the degree of public acceptance and willingness to actively support transition processes, and by organizational, political, and institutional conditions. The interdependencies between the different system components have to be considered here in particular, to be able to achieve integrated results. Thus, IWRM can serve as a driving force for technological as well as organizational or social innovations that are needed to realize the sustainability targets in the water sector.

In the case of the IWRM Indonesia project which is presented in this special issue, the fresh water situation in the area under investigation in the Gunung Kidul Province (Central Java, Indonesia) is characterized by a monsoon climate leading to water abundance during the rainy season and severe scarcities during the dry season. The impact of water scarcity is aggravated by the karstic geology that causes a rapid seepage of rainwater into underground drainage systems and caves. This is one reason why this region is considered to be one of the poorest regions in Indonesia and is included in the list of the most disadvantaged regions by the Indonesian Ministry for the Development of Disadvantaged Regions (KEMENNEG PDT 2005). In the year 2002, the installation of the Bribin supply scheme, based on a hydropower-driven water supply plant, was initiated. This scheme allows for using underground water resources (Nestmann et al. 2009), and in the framework of a collaborative research project, funded by the German Federal Ministry for Education and Research (BMBF), (Nestmann et al. 2010), it was further developed into an integrated water management plan for the whole region.

To make matters worse, water resources in the project area are highly vulnerable due to the often lacking filtration of pollutants in the underground and the quick transport of underground water through the karst drainage systems. In addition, the existing sanitation system suffers from a poor standard of planning, designing, and operation.
Predominantly, the used technologies are not capable to retain hygienic and chemical pollution from the environment resulting in health risks for the population. A considerable improvement of the sanitation system is even more urgent, because the newly developed underground water resource could secure permanently water supply for 75,000 people in the Bribin distribution area over the past 4 years (Oberle et al. 2016), and thus has to be protected against pollution.

IWRM-related research has to take into account the integration aspects mentioned above. Within the IWRMIndonesia project, the main task of the sub-project described here was to provide knowledge and tools to contribute to an improved dealing with the following questions: how can the sustainability performance of fresh water supply technologies that are implemented or discussed in the area under investigation be optimized? How can life-cycle thinking be suitably included in this analysis? Which sanitation technologies perform best with respect to sustainability under the regional framework conditions? How can the knowledge about sustainability in the sanitation sector be transferred into operable planning steps to improve the sanitation situation in a developing country? The knowledge and instrumental basis should be used to contribute to an improvement of the resilience of the natural system and the socio-technical water system in the region, a reduction of existing vulnerabilities, and an improvement of system adaptability against changing climatic, economic, or political framework conditions.

\section{Methods}

Methodologically, this was done by carrying out integrative sustainability analyses and adopting a systems analytical perspective. In the case of the sanitation-related analysis, this was embedded in the development of an innovative planning tool and its application to a pilot village within the area under investigation (see "The sustainability-based sanitation planning tool (SusTA)"). In the case of the fresh water-related analysis, the sustainability assessment of technologies was combined with a life-cycle approach (see "Life Cycle Analysis: LCA and LCC"). Both perspectives were complemented by an analysis of the vulnerability of the karstic water resource in the water catchment area, addressing causes, impacts, and solution options.

In a broader sense, systems' analysis is a general methodology (not a fixed set of techniques) that applies a 'systemic', comprehensive perspective by taking into account all relevant aspects and elements of a situation or a research question, particularly the interactions between different elements. This is a suitable approach, especially 
in the cases of complex, multi-sectoral, multi-scale, or multi-actor contexts, such as the socio-technical water management system. It provides a framework for collecting, integrating, and interpreting different knowledge elements to support decision-making processes.

The integrative sustainability concept of the German Helmholtz association, developed by Kopfmüller et al. (2001), provided the necessary conceptual basis for the sustainability assessments carried out in the project. In distinction from the vast majority of existing sustainability concepts which focus on the classical "pillars" of economic, ecological, and social aspects, the Helmholtz concept starts from three constitutive elements of sustainability: (1) the postulate of inter- and intra-generational justice as basis for the organization of societies, (2) the global perspective, and (3) an "enlightened" anthropocentrism denying own "rights" for the natural environment, but including an obligation for mankind to interact cautiously with nature based on a well-understood selfinterest. At its core, the concept consists of a set of sustainability rules which substantiate these constitutive elements (for more details, see "Methods"). These rules serve as a goal orientation for future development and for societal learning processes, and also as a basis for criteria to assess development performances, both requiring substantiation by indicators and target values. To date, this concept is still one of the very few scientific concepts that are applied systematically in a range of research projects and consultancy activities within and outside Germany.

In the field of freshwater supply, the sustainability assessment of different technological options could be carried out by applying already developed methods, such as life-cycle assessment (LCA) and life-cycle costing (LCC), to the extent information needed for this assessment, for example, data on alternative water extraction, water distribution, and water treatment technologies, and was available. The results of the assessments can be used, e.g., for decision support within the IWRM. In the case of sanitation technologies, where information on suitable technologies was still lacking at the time of this project, a new additional decision support tool had to be developed. Since many sanitation technologies often do not work in the context of rural conditions in developing countries, the new assessment tool needs to include aspects regarding a suitable realization of the intended use of the technologies.

\section{The sustainability-based sanitation planning tool (SusTA)}

In the real world of planning, decision makers and project implementers need a planning tool to realize projects suitably. Sanitation is considered as a particularly sensitive topic. It addresses a basic need, but many beneficiaries are not open enough to discuss this issue. In many developing countries where water supply and sanitation facilities have already been installed, it is estimated that $30-60 \%$ of existing rural systems are inoperative at any given time (Brikké and Bredero 2003). In addition to technical failures, many disfunctionalities in sanitation facilities are the result of a wrong selection of technologies which do not suitably meet the needs of the beneficiaries.

To avoid this problem, several organizations and agencies that are involved in the sanitation sector have developed planning tools. Some of these tools put emphasis on changing community's behavior related to sanitation. Others focus on technology implementation and provide different frameworks to select a technology. The approaches of open planning and HCES (Eawag 2005) are equipped with a selected list of technological options. Sanitation 21 and CLUES (Lüthi et al. 2011) prescribe a generic analysis of several sanitation systems. Although technology selection criteria are provided by some tools, there is no clear indication which conditions have to be fulfilled to meet these criteria. Specifically, there is no reference to what is meant by a sustainable technology for a particular context.

The sustainability-based sanitation planning tool (SusTA) described here is designed to fill this gap. It shall provide support to sanitation planners, project implementers, and decision makers in developing countries to select the most sustainable sanitation technology for a given context by considering beneficiaries' concerns. As a part of the tool, SusTA tries to offer a transparent assessment, based on a rather simple method using only few data, to provide an operable tool for developing countries' contexts.

Developing a planning tool requires both, a conceptual and an empirical basis. It requires many observations about the interaction between sanitation-related stakeholders, technology developers, practical users, and the environment. For this reason, a case study area which experiences common problems in developing countries was needed, to first apply and test the tool. The village of Pucanganom in Gunung Kidul, Java, Indonesia was selected for this. This village is located in the catchment area of the newly developed freshwater resource, the underground Bribin river, and represents a village experiencing a top-down planning approach, where no systematic sustainability assessment is carried out to date. Figure 1 shows the three general stages of developing a planning tool.

In general, planning tools for the implementation of technologies consist of five basic steps as concluded by McConville (2010): (1) problem identification, (2) definition of objectives, (3) design of alternative options, (4) technology selection process, and (5) development of an

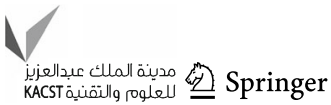


Fig. 1 Three stages in the development of sanitation planning tool

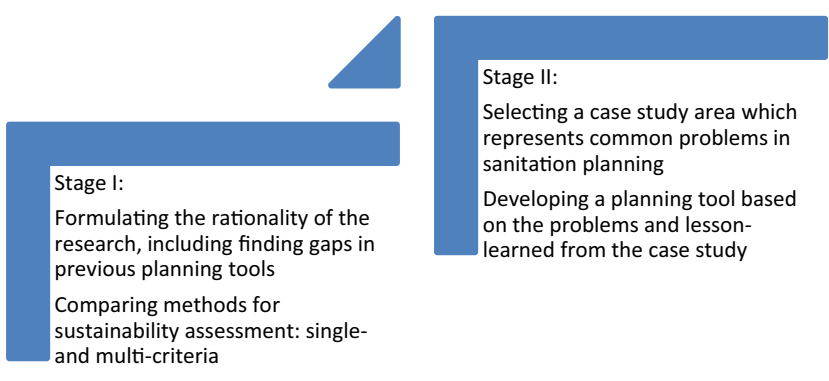

Stage III:

Contextualizing the tool for the case study 's level

Providing analytical generalization of the tool for cases with similar conditions to the case study

Analysis of the strengths and weaknesses of the tool

Table 1 Basic planning and SusTA planning steps

\begin{tabular}{|c|c|c|c|c|}
\hline \multirow{2}{*}{$\begin{array}{l}\begin{array}{l}\text { Level of } \\
\text { analysis }\end{array} \\
\begin{array}{l}\text { Regional level } \\
\text { analysis }\end{array}\end{array}$} & \multirow{2}{*}{$\begin{array}{l}\text { Basic planning steps } \\
\text { Problem } \\
\text { identification }\end{array}$} & \multicolumn{2}{|c|}{ SusTA's planning steps } & \multirow{2}{*}{$\begin{array}{l}\text { Supporting tools } \\
\text { Adopting planning domains } \\
\text { approach of HCES (Eawag } \\
\text { 2005) }\end{array}$} \\
\hline & & 1 & $\begin{array}{l}\text { Stakeholders and sanitation policy analysis in the region (SHA } \\
\text { step) } \\
\text { This step reviews sanitation policy and financial scheme which } \\
\text { affect the selection of a sanitation system in the project }\end{array}$ & \\
\hline & $\begin{array}{l}\text { Problem } \\
\text { identification, } \\
\text { definition of } \\
\text { objectives }\end{array}$ & 2 & $\begin{array}{l}\text { Distance-to-target analysis regarding the sustainability of the } \\
\text { sanitation situation in the region (DTA step) } \\
\text { A set of background indicators is used to analyze sustainability } \\
\text { deficits and problems in sanitation development in the region. } \\
\text { The results of this identification should be considered for } \\
\text { defining the measurements- including sanitation technology in } \\
\text { the project area }\end{array}$ & $\begin{array}{l}\text { A set of background indicators to } \\
\text { conduct distance-to-target } \\
\text { analysis }\end{array}$ \\
\hline \multirow[t]{3}{*}{$\begin{array}{l}\text { Project/case } \\
\text { study-level } \\
\text { analysis }\end{array}$} & \multirow[t]{2}{*}{ Designing option } & 3 & $\begin{array}{l}\text { Examination of physical and socio-economic conditions in the } \\
\text { project area (PSE step) } \\
\text { Household questionnaire is used for data collection and mean to } \\
\text { examine the physical and socio-economic conditions. Based on } \\
\text { this examination, technology options which are suitable for the } \\
\text { area can be identified }\end{array}$ & A set of household questionnaire \\
\hline & & 4 & $\begin{array}{l}\text { Contextualization of technology assessment process (CTX step) } \\
\text { A set of technology assessment indicators is designed to evaluate } \\
\text { technology options (these technology options have been } \\
\text { identified from step } 2 \text { and 3). Each indicator has a rating scale } \\
\text { (low-medium-high) to correspond to the technology's degree } \\
\text { of fulfillment to the indicator. However, each project area has } \\
\text { different criteria for what is meant by "low", "medium" or } \\
\text { "high fulfillment". Therefore, these fulfillments should be } \\
\text { contextualized }\end{array}$ & $\begin{array}{l}\text { A set of technology assessment } \\
\text { indicators to evaluate the } \\
\text { technology options }\end{array}$ \\
\hline & Selection process & 5 & $\begin{array}{l}\text { Sustainability-based technology assessment (STA step) } \\
\text { After defining the options of sanitation systems (technology and } \\
\text { management) for the project area, these options are evaluated } \\
\text { using the indicators set. Based on the results of this analysis, } \\
\text { the most sustainable sanitation system for a given context is } \\
\text { selected }\end{array}$ & \\
\hline
\end{tabular}

implementation plan. The main differences between existing planning tools exist with respect to the emphasis of each step and to whether or not the tool includes action planning after the selection of a technology.

Following the five planning steps of McConville (2010), the SusTA steps are outlined in Table 1.

\section{Life-cycle analysis: LCA and LCC}

In the field of freshwater analysis, the established methods of LCA and LCC were used for a quantitative assessment of potential environmental impacts and costs along the life cycle (LC) of products and services-or, specifically in this 
project, of different technologies-to provide valid information to realize optimization potentials and for appropriate decision support. LCA and LCC are relevant tools within sustainability assessments, because the LC perspective helps to avoid a shift of burden between life-cycle phases or to future generations. Specifically, with LCA and LCC, the inputs and outputs of a product (e.g., materials, energy, costs and emissions, and costs/revenues, respectively) are analyzed for all phases of raw material production, manufacturing, use of products, recycling, and disposal. This LC perspective as well as the reference to the so-called functional unit (fU) distinguishes LCA and LCC from other existing environmental and economic assessment methods. The fU is the "quantified" function, which serves as reference unit for calculations and allows for assessing alternative products and services by assigning them the same function (ISO 2006a, b; Hunkeler et al. 2008; Swarr et al. 2011).

Within the application of the Sustainability concept of the Helmholtz Association, LCA and LCC (besides other methods) are used as tools for assessing environmental and economic aspects of sustainability. In the IWRM project, LCA and LCC were used for analyzing alternative technology options for water supply (extraction); distribution and treatment within the area of investigation to identify which of the potential alternatives are "more" sustainable. A "more" sustainable option is here understood as the option, which shows a better environmental and economic performance compared to its alternatives. In addition, LCA and LCC were used to assess the environmental impacts and costs/benefits of the oldwater supply system which existed before the IWRM activities, and the projected new system after an implementation of selected technology options within the IWRM. Various LCA studies assessing different technologies for water supply, distribution, and treatment are already available (an overview is provided, e.g., by Lassaux et al. 2007). For LCC, only few studies are available (e.g., Barriosa et al. 2008; Ghimire et al. 2012; Ambrose et al. 2008). However, most of these LCA and LCC studies focus on urban systems in industrialized countries. Thus, the studies conducted within this IWRM project can be seen as one of the first cases focusing on rural regions in developing or emerging countries. Moreover, it was the first time that LCA and LCC were used within an IWRM project as part of a sustainability assessment of technologies.

The several technology options for the different processes of the water sector, i.e., water supply, distribution, and treatment, considered for the LCA and LCC studies, included existing technologies in the investigation area as well as technologies proposed and/or implemented within the IWRM project. The main processes are analyzed, and the technology options are presented in Fig. 2.

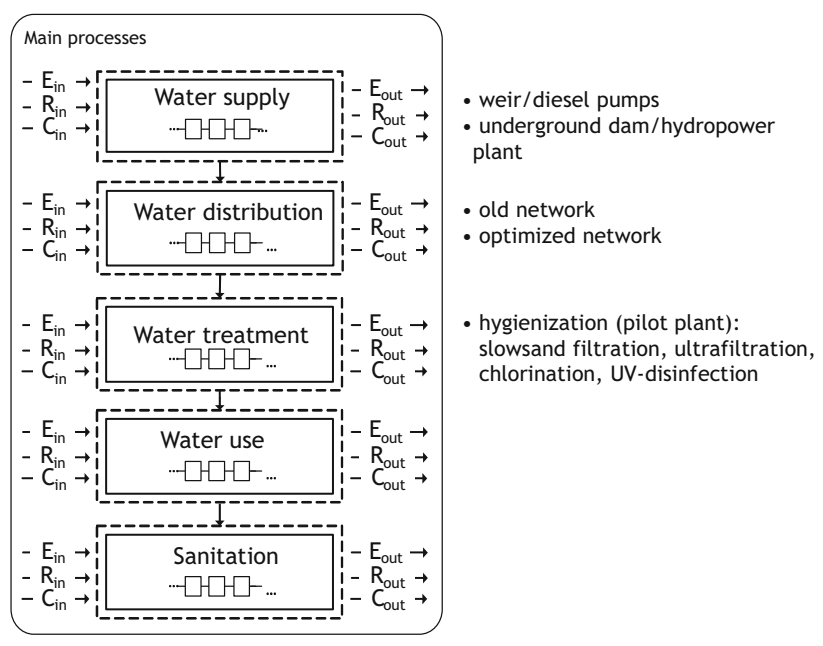

E: energy R: resources (raw materials) C: costs/revenues

Fig. 2 Main processes in the water supply system and alternative technology options considered for the LCA and LCC studies with focus on freshwater supply, i.e., water supply (extraction), distribution, and treatment

The data for modeling the technology options, i.e., their inputs and outputs, were obtained from IWRM project reports (e.g., IWRM 2011), from discussions with project partners (specific data), available international LCA databases (e.g., ecoinvent 2007), and generic data from the literature. All processes, from raw material extraction to the use phase, were included. The end-of-life phase of the technology options (recycling/disposal) was not considered in these studies due to a lack of data, but described qualitatively as far as possible. Detailed information about the modeling approach and the data used can be found in Lehmann (2013). The LCA studies analyzed the following potential environmental impacts (impact categories) using the CML method, developed at the "centrum voor milieukunde" (CML) of the Leiden University in The Netherlands, a commonly used impact assessment method in current LCA practice (CML 2001):

- global warming (GWP100);

- acidification (ADP);

- eutrophication (EP);

- abiotic resource depletion (AP);

- ozone depletion (ODP);

- human toxicity (HTP);

- terrestrial ecotoxicity (TETP);

- aquatic and marine ecotoxicity (FAETP and MAETP);

- photochemical ozone formation (POFP).

For the LCC studies, the following indicators were considered:

- initial investment costs and

- operating costs. 


\section{Results}

\section{The sustainability-based sanitation planning tool (SusTA)}

The technology options which are appropriate for a particular context can be identified from step 2 and 3 of SusTA. This paper will focus only on the technology assessment part (step 4 and 5). Details about other steps of SusTA can be found in Nayono (2014).

The identified options of step 2 and 3 are then evaluated using a set of multi-criteria technology assessment indicators (step 4 and 5 of SusTA), which have been derived from the integrative Helmholtz concept of sustainability (Kopfmüller et al. 2001). The indicators are presented in Table 2.

The set of indicators is ranked by the main stakeholders in the wastewater sector, which have been identified within the first step of SusTA, namely:

- institutions (authority, governmental agency);

- practitioners (non-governmental organization, consultants) and

- users/beneficiaries (common users and users who also serve as village administrators and operators).

A simple ranking approach is applied due to the fact that there is a big gap of knowledge between stakeholders. Practically, some stakeholders might have difficulties using other methods, such as weighting the indicators or using the analytical hierarchy process (Saaty 1980). Assuming that each stakeholder has the same power and there is no weight of power considered, the results of indicators' ranking are shown in Fig. 3.

The ranking is obtained by taking the average numerical values assigned by all stakeholders to each indicator. Based on this, "the investment cost" becomes the most important indicator (low numerical value), while "potential energy recovery of a system" is considered as the least important (high numerical value). The differing opinions of the stakeholders are captured in "operational and maintenance cost". In the case study area, operational and maintenance $(\mathrm{OM})$ costs of a system are born by the users. Therefore, it becomes their prime concern. The "biochemical oxygen demand (BOD) removal efficiency" indicator (measuring the remaining biodegradable organic matters in the effluent) represents a particular environmental performance of a system. This indicator was ranked most controversially between stakeholders, being a crucial issue for practitioners (designer) and institutions (regulator), and, contrary to them, less important to the users.

After the indicators are ranked, the next step is to propose the assessment method and fulfillment conditions of all indicators. To select a proper assessment method for each indicator, the main question is how can a certain indicator be assessed? In the case study area, many data are not available. Therefore, the most appropriate method is selected with a primary concern for data availability. In defining the fulfillment conditions for each indicator, a rating method (using scale 1-3) is developed. Here, a value of 1 represents the highest fulfillment, and a value of 3 represents the lowest fulfillment. This rating method is important to provide transparency in the analysis, so that technologies can be compared using the same assessment basis. Some examples of the rating values and their fulfillment conditions are given in Table 3.

The boundaries for fulfillment conditions are obtained from several references (see Table 3, column 6), such as national/local regulation (e.g., indicator concerning investment costs), a combination of survey and stakeholders' opinions (e.g., indicator concerning water consumption), and own observations of the author (e.g., indicator concerning technical skill). Some of these conditions are applicable to other contexts (e.g., technical skill). For some boundary conditions which are only suitable for particular cases (e.g., water consumption and investment cost), hints for an adaptation to other contexts are provided (see Table 3, column 7).

The pilot case of IWRM Indonesia is located in a part of the village Pucanganom, with 741 inhabitants or 196 households (ITAS, KIT, and Faculty of Geography, UGM 2010). There is a sinkhole located in the middle of the rural settlements known as Kalen sinkhole, or in the local language, Luweng Kalen surrounded by settlements in higher elevation; the sinkhole becomes an entrance point of pollutants, which are flushed to the sinkhole by heavy rainfall. Based on a vulnerability analysis (Heckmann 2011) and tracer tests (Eiche et al. 2013), it is proven that the sinkhole is connected to the Bribin system. Therefore, pollutants entering the sinkhole threaten the water quality of the Bribin water supply system. Table 4 describes the types of major pollutants and their common treatment in the village of Pucanganom.

To prevent future contamination, two sanitation systems have been constructed in the village of Pucanganom by two different projects (System I and System II). For comparison, an additional alternative sanitation system is proposed in this analysis (System III). System III is proposed as the result of step 2 and 3 of SusTA. All three systems consist of two sub-systems (sub-systems a and b), which are installed at different scales and management levels: private/single household, shared facility in a cluster (3-6 households), or communal facility ( 38 households).

These three system options are then analyzed using a set of sustainability-based technology assessment 
Table 2 Selected indicators developed based on the rules of the Helmholtz concept

\begin{tabular}{|c|c|}
\hline Rules & Indicators \\
\hline Protection of human health & $\begin{array}{l}\text { Health risks caused by the system } \\
\text { Refers to potential health impact in dealing with a sanitation system and the ability of the system to } \\
\text { break the cycle of diseases }\end{array}$ \\
\hline $\begin{array}{l}\text { Ensuring satisfaction of basic needs } \\
\text { (sanitation) }\end{array}$ & $\begin{array}{l}\text { Compatibility with the existing sanitation system (in case an existing system is available) } \\
\text { Refers to the technical characteristics of a sanitation system regarding its functionality when } \\
\text { connected to an existing system } \\
\text { Investment costs } \\
\text { Refers to the construction costs (land, material, manpower) } \\
\text { Operational and maintenance cost } \\
\text { Refers to the operational and maintenance cost (expenditure for personnel, energy supply, water } \\
\text { supply, chemicals, spare parts, etc.) } \\
\text { Technical skills required to operate and maintain the system } \\
\text { Refers to the simplicity of the system in relation to its operation, maintenance and level of personnel } \\
\text { skills required. } \\
\text { Possibility of minor problems to be fixed within reasonable repair time } \\
\text { Refers to the availability of materials and support during the operational phases, and an indication of } \\
\text { whether procurement and services are available within reasonable repair time }\end{array}$ \\
\hline $\begin{array}{l}\text { Sustainable use of non-renewable and } \\
\text { renewable resources }\end{array}$ & $\begin{array}{l}\text { Land required for the treatment plant } \\
\text { Indication of the land needed to construct and operate the system } \\
\text { Natural resource consumption to operate the whole system }{ }^{\mathrm{a}} \\
\text { Indication of the use of additional natural resouces required to operate the system } \\
\text { Energy (electricity, fossil fuels) required to operate the system } \\
\text { Indication of the use of resources needed to operate the system } \\
\text { Potential nutrient recovery (in case resources recovery is applied) Refers to the usable by- and end- } \\
\text { product of the system } \\
\text { Potential energy recovery } \\
\text { (in case resource recovery is applied) } \\
\text { Refers to the usable by- and end product of the system }\end{array}$ \\
\hline Sustainable use of the & System's removal efficiency ${ }^{b}$ \\
\hline environment as a sink & $\begin{array}{l}\text { Refers to the technical function and ability of the system to remove pollutants and meet the required } \\
\text { standards }\end{array}$ \\
\hline $\begin{array}{l}\text { Participation in } \\
\text { social decision-making } \\
\text { processes }\end{array}$ & $\begin{array}{l}\text { Public preference of technology } \\
\text { Indication of public acceptance for using, maintaining and sustaining the system }\end{array}$ \\
\hline
\end{tabular}

${ }^{a}$ Natural resource in this context is meant as a scarce resource that is needed to operate the sanitation system. In the case study, water is scarce but nevertheless is required to operate the system

b Total suspended solids (TSS) and biochemical oxygen demand (BOD) are two universally used effluent-related indicators by which the performance of treatment plants is judged for regulatory control purposes (Tchobanoglous et al. 2003). Therefore, TSS and/or BOD removal efficiency can be used as indicators to express technical functionality. For this case study (village Pucanganom) TSS removal of a technology is actually more relevant than BOD removal. Due to data limitation, in this paper BOD removal efficiency is used to assess the technology options

indicators. The ranking of indicators is expressed in a clockwise direction (first rank investment cost, second rank OM cost, and so on). Detailed matrixes and analysis can be found in Nayono (2014). The indicators' scoring for Systems I, II, and III is presented in a rose-chart diagram (Fig. 4). The diagram shows the distance of each indicator's value to the target (the center of the diagram). The closer the distance to the center, the higher the degree of target fulfillment of this indicator for a certain system (Table 5).
After all the systems are assessed using these indicators, the selection of the most sustainable system can be based on several methodological options:

- Single indicators, such as social preference, health risk, or investment costs.

- Particular sustainability dimension (e.g., economy investment and OM costs).

- Distance-to-target considerations, e.g., number of indicators close (to be defined) to the targets. 
Fig. 3 Indicators ranking by stakeholders

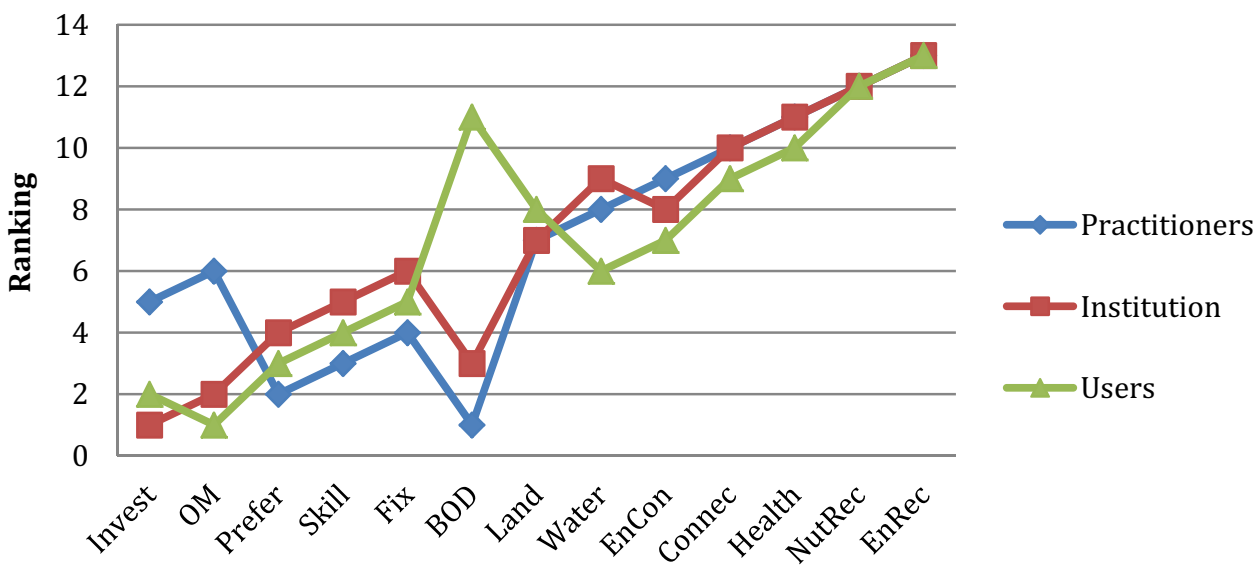

Table 3 Conditions to achieve indicator targets

\begin{tabular}{|c|c|c|c|c|c|c|}
\hline \multirow[t]{2}{*}{ Indicator } & \multirow[t]{2}{*}{ Measurement } & \multicolumn{3}{|c|}{ Degree of target fulfillment } & \multirow[t]{2}{*}{ Reference for fulfillment } & \multirow{2}{*}{$\begin{array}{l}\text { Adaptation to other } \\
\text { contexts }\end{array}$} \\
\hline & & High (1) & Medium (2) & Low (3) & & \\
\hline $\begin{array}{l}\text { Investment } \\
\text { costs (cost } \\
\text { components: } \\
\text { land, } \\
\text { material, } \\
\text { manpower) }\end{array}$ & $\begin{array}{l}\text { Quantitative } \\
\text { (USD/house- } \\
\text { hold) }\end{array}$ & $<438$ & $438-876$ & $>876$ & $\begin{array}{l}\text { These values are the amount } \\
\text { that Indonesian government } \\
\text { should bear for a sanitation } \\
\text { facility according to } \\
\text { country's budget scheme }\end{array}$ & $\begin{array}{l}\text { The threshold values } \\
\text { should be adapted } \\
\text { according to the } \\
\text { respective sanitation } \\
\text { budget scheme in a } \\
\text { certain country }\end{array}$ \\
\hline $\begin{array}{l}\text { Technical skills } \\
\text { required to } \\
\text { operate and } \\
\text { maintain the } \\
\text { system }\end{array}$ & $\begin{array}{l}\text { Semi-quantita- } \\
\text { tive }\end{array}$ & $\begin{array}{l}\text { No special } \\
\text { skills } \\
\text { required. } \\
\text { Information } \\
\text { before } \\
\text { dealing } \\
\text { with the } \\
\text { system is } \\
\text { enough }\end{array}$ & $\begin{array}{l}\text { Moderate skill } \\
\text { required, can } \\
\text { be obtained } \\
\text { from training } \\
\text { on regular } \\
\text { basis }\end{array}$ & $\begin{array}{l}\text { Special skill } \\
\text { required, } \\
\text { intensive } \\
\text { training/ } \\
\text { is } \\
\text { required }\end{array}$ & $\begin{array}{l}\text { The assessment considers the } \\
\text { baseline knowledge and skills } \\
\text { of available human resources }\end{array}$ & $\begin{array}{l}\text { These boundary conditions } \\
\text { are applicable for other } \\
\text { contexts }\end{array}$ \\
\hline $\begin{array}{l}\text { Water } \\
\text { consumption } \\
\text { to operate the } \\
\text { whole system }\end{array}$ & $\begin{array}{l}\text { Quantitative } \\
\text { (liter/ } \\
\text { household.day }\end{array}$ & $<40$ & $40-60$ & $>60$ & $\begin{array}{l}\text { The values are gained from } \\
\text { calculation based on } \\
\text { questionnaires in the pilot } \\
\text { village }\end{array}$ & $\begin{array}{l}\text { The threshold values are } \\
\text { influenced by the daily } \\
\text { water consumption and } \\
\text { water availability in the } \\
\text { households }\end{array}$ \\
\hline
\end{tabular}

Source: Nayono (2014)

Table 4 Main pollutants and their common treatments in Pucanganom (Source: ITAS, KIT and Faculty of Geography, UGM 2010)

\begin{tabular}{lc}
\hline Main types of pollutants & Common treatment \\
\hline Greywater & $86 \%$ of respondents simply discharged their greywater to the surface \\
Water generated from washing food and dishes (kitchen), & \\
washing clothes and as well as from bathing (bathroom) & \\
Blackwater & $68 \%$ of the respondents used pour-flush siphon toilets \\
Wastewater originates from toilet, mixture of urine, feces and & $\begin{array}{c}96.3 \% \text { of them equipped their siphon toilet with a single permeable hole } \\
\text { connected by a pipe to the toilet }\end{array}$ \\
flushing water & $\begin{array}{c}100 \% \text { of the respondents collected the dung nearby the stall during the rainy } \\
\text { Cattle dung }\end{array}$ \\
From cows and goats & season and dry it during the dry season for further use as fertilizer
\end{tabular}

${ }^{a}$ Defined by Gajurel, 2003; Tilley et al. 2008 
Fig. 4 Sustainability-based technology assessment of three sanitation systems in the pilot village of Pucanganom

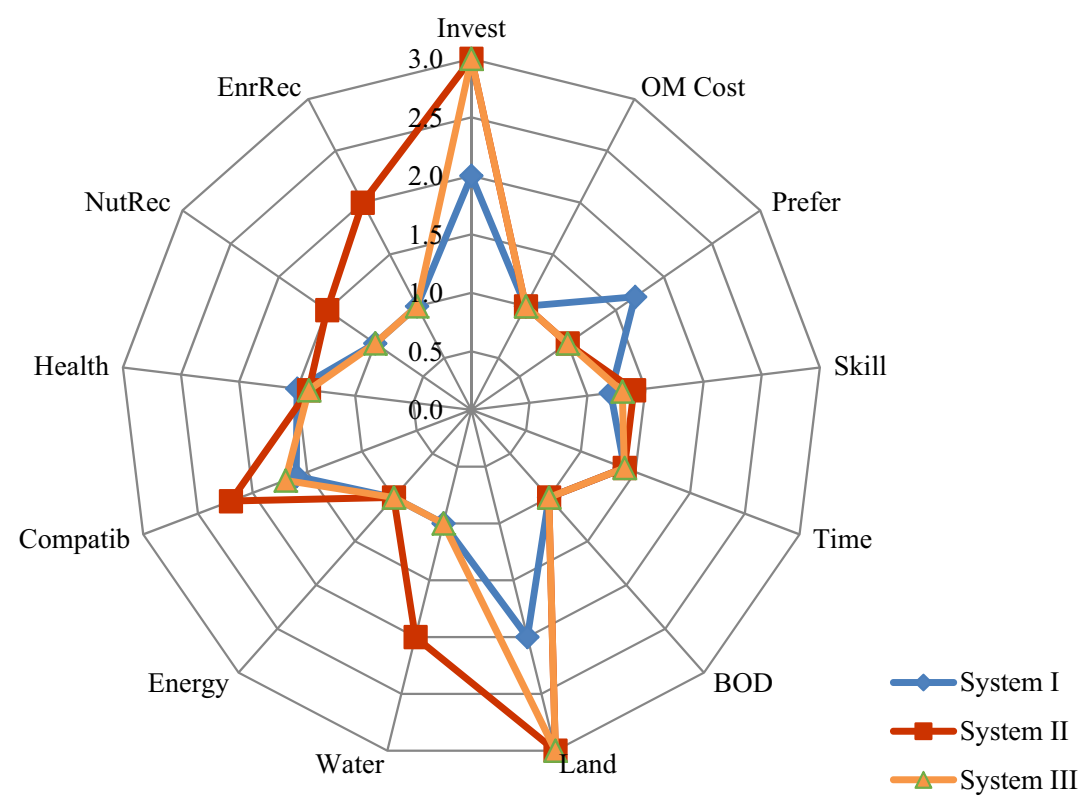

- Aggregating the scores into an index (not provided in this paper).

Figure 4 reveals that System I has the least investment cost and land requirement. This is due to the fact that the system is installed at a cluster level, which saves land and investment costs considerably compared to a single-household system. Despite all those positive factors, System I is the least preferred compared to the other two systems. One reason for this is that the shared digester [sub-system I (a)] uses cattle dung and black water as input. Culturally and religiously, slurry from human feces (humanure) is less acceptable in the society. The digester which requires a shared responsibility is more complicated compared to a singlehousehold level digester. Therefore, System I is technically and economically feasible, but has low social acceptance.

System II includes the highest investment and OM costs. The sewerage and ABR require an operator and additional water resources, while on the other side, the region experiences seasonal water scarcity. Moreover, the system cannot fully recover the resources and does not recover any energy to reduce the OM costs. Due to the fact that there is no sharing of responsibility or end products, this system is not susceptible to arising conflicts.

Regarding social acceptance, System III can be considered as a reasonable compromise. Although the investment cost of this system is higher compared to System I, it is lower than in the case of System II. This high investment cost resulted from the construction of a private digester, and separate treatment of cattle dung and black water. Nevertheless, this system has advantages: the private facility does not create conflicts, which commonly occurred in a shared facility. Moreover, the end product (slurry and biogas) resulting only from cattle dung is highly accepted, compared to the one from the mixture of cattle dung and black water. 
Table 5 Characteristics of three different sanitation systems (System I, System II and System III) in the case area

\begin{tabular}{|c|c|c|c|c|}
\hline System & Input & Treatment & $\begin{array}{l}\text { Scale, } \\
\text { management } \\
\text { level }\end{array}$ & $\begin{array}{l}\text { End product in on-site/semi- } \\
\text { off site level }\end{array}$ \\
\hline (a) & Cattle dung, blackwater & Biogas digester & $\begin{array}{l}\text { Shared facility in } \\
\text { cluster } \\
\text { (3-6 households) }\end{array}$ & $\begin{array}{l}\text { Slurry (usable) } \\
\text { Biogas (usable) }\end{array}$ \\
\hline (b) & $\begin{array}{l}\text { Greywater (kitchen, } \\
\text { bathroom) }\end{array}$ & Horizontal-flow planted filter (HFPF) & $\begin{array}{l}\text { Shared facility in } \\
\text { cluster } \\
\text { (3-6 households) }\end{array}$ & $\begin{array}{l}\text { Biomass (usable) } \\
\text { Effluent (infiltrated) }\end{array}$ \\
\hline \multirow[t]{2}{*}{ II (a) } & Cattle dung & Biogas digester & $\begin{array}{l}\text { Private } \\
\text { (1 household) }\end{array}$ & $\begin{array}{l}\text { Slurry (usable) } \\
\text { Biogas(usable) }\end{array}$ \\
\hline & $\begin{array}{l}\text { Blackwater, greywater } \\
\text { (kitchen, bathroom) }\end{array}$ & Anaerobic baffled reactor & $\begin{array}{l}\text { Communal } \\
\text { facility } \\
38 \text { households) }\end{array}$ & $\begin{array}{l}\text { Faecal sludge (needs further } \\
\text { treatment) } \\
\text { Effluent (discharged into } \\
\text { nature) }\end{array}$ \\
\hline \multirow[t]{2}{*}{ III (a) } & Cattle dung & Biogas digester & $\begin{array}{l}\text { Private } \\
\text { (1 household) }\end{array}$ & $\begin{array}{l}\text { Slurry (usable) } \\
\text { Biogas (usable) }\end{array}$ \\
\hline & $\begin{array}{c}\text { Blackwater, greywater } \\
\text { (kitchen, bathroom) }\end{array}$ & $\begin{array}{l}\text { Septic tank combined with anaerobic filter, and } \\
\text { horizontal-flow planted filter }\end{array}$ & $\begin{array}{l}\text { Shared facility in } \\
\text { cluster } \\
\text { (4-5 households) }\end{array}$ & $\begin{array}{l}\text { Faecal sludge } \\
\text { (needs further treatment) } \\
\text { Biomass (usable) } \\
\text { Effluent (usable/infiltrated) }\end{array}$ \\
\hline
\end{tabular}

\section{LCA and LCC}

The results of the LCA and LCC studies show that potential environmental impacts and costs (for technology users) related to the technologies considered derive mainly from the technologies' energy demand. Detailed results of the LCA and LCC studies on different technologies of water supply, distribution and treatment as well as detailed descriptions of challenges of modeling the technologies can be found in Lehmann (2013). An example for one of the LCA results is presented in Fig. 5. The figure compares the potential environmental impacts related to the provision of $1 \mathrm{~m}^{3}$ water of the new plant (underground dam with hydropower plant), including the new distribution system (i.e., distribution with an optimized network), and the old plant (weir with diesel pumps), including the old distribution system (i.e., distribution with the old network). For a relative comparison of the new and the old plants and systems, the total potential environmental impacts of the old plant/system are set to $100 \%$ (see columns 1 in Fig. 5). These columns serve as reference in three respects:

First, they can be regarded as relative potential environmental impacts of water supply by the old plant (without considering water distribution). The LCA showed that water supply with the new plant (Fig. 5, columns 4) leads to a decrease of environmental impacts of more than $90 \%$ related to the provision of 1 cubic meter water. The main reason for the better environmental performance of the new plant is the substantially reduced energy demand for water extraction (hydropower plant instead of diesel pumps). However, in water supply systems, a major part of energy demand is accounted to the distribution of water.

Therefore, in a second analysis, the potential environmental impacts are calculated for water supply including distribution. In Fig. 5, both distribution by the new optimized network and by the old network is considered. To illustrate the influence of the new network, columns 1 now can be regarded as the relative potential environmental impacts of water supply by the old plant including an assumed water distribution within the new network. It is shown that the new system still can lead to a reduction of potential environmental impacts of 40-70\% (columns 2), mainly due to the significant energy savings caused by the new plant for water extraction.

Finally, to illustrate the influence of the old network, columns 1 in Fig. 5 can also be regarded as relative potential environmental impacts of water supply by the old plant including an assumed water distribution within the old network. It is shown that by implementing the new system, i.e., the projected water supply and new optimized network (Fig. 5, columns 3), potential environmental impacts related to water provision can be reduced up to $90 \%$ compared to the old system (existing water supply and old network).

A highly aggregated summary of the evaluation of alternative technologies for water supply and distribution as well as water treatment, based on the LCA and LCC 


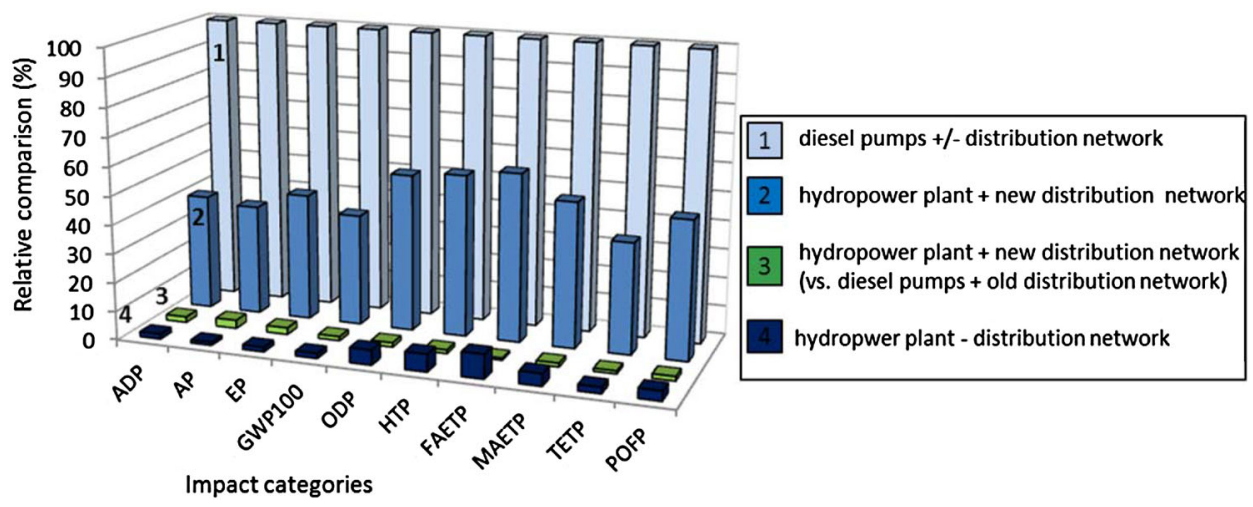

Fig. 5 Relative comparison of potential environmental impacts related to the provision of $1 \mathrm{~m}^{3}$ water resulting from water extraction by the old plant, i.e., weir and diesel pumps (columns 1 , as reference set to $100 \%$ ) and the new plant, i.e., underground dam and hydropower plant including water distribution (columns 2) and without water distribution (columns 4) (adapted from Lehmann 2013)

Table 6 Highly aggregated evaluation of alternative technology options for water supply based on the LCA and LCC studies with regard to their environmental and economic performance

Environmental and economic performance of alternative technology options

\begin{tabular}{lc}
\hline "more sustainable" & less sustainable" \\
\end{tabular}

Water supply and distribution

$\begin{array}{llc}\begin{array}{l}\text { Environmental } \\ \begin{array}{l}\text { Economic } \\ \text { (operation) }\end{array}\end{array} & \begin{array}{c}\text { Underground dam/hydropower plant and optimized distribution system } \\ \text { (projected system) }\end{array} & \begin{array}{c}\text { Weir/diesel pumps and old distribution system } \\ \text { (existing system) }\end{array} \\ \begin{array}{l}\text { Economic (initial } \\ \text { costs) }\end{array} & \text { Weir/dieselpumps and old } & \text { Weir/diesel pumps and old distribution system } \\ & \text { Distribution system } & \text { Hydropower plant and optimized distribution } \\ \text { system }\end{array}$

Water treatment (hygienization)

$\begin{array}{lll}\text { Environmental Chlorination, UV-disinfection, sandfiltration } & \text { Ultrafiltration }\end{array}$

Economic Chlorination, UV-disinfection, sandfiltration Ultrafiltration

studies with regard to their environmental and economic performance, is provided in Table 6. According to this evaluation and based on the assumptions taken for the modeling (see Lehmann 2013 for further information), the projected system for water supply/distribution is "more" environmentally sustainable than the existing system, more cost efficient during the operation phase, but also associated with high initial costs.

Regarding water treatment technologies, the analyses showed that ultrafiltration seems to be "less" environmentally sustainable and less cost efficient than the three other technologies considered, i.e., chlorination, UV disinfection and sand filtration.

\section{Discussion and outlook}

The essential objective of the development and application of the methods outlined in this article is to improve basic system knowledge about the fresh- and wastewater sector in the region, orientation knowledge about the targets a society strives for, and action knowledge about suitable pathways and related technologies to achieve them, in order to support and improve decision-making at different spatial and institutional scales. Answering the questions at the end of "Background and objectives of the work", it can be stated that a holistic view on the sustainability performance of fresh water supply and sanitation technologies needs a profound theoretical and conceptual basis which could be found in the integrative sustainability concept of the German Helmholtz Association. Its basic approach could be concretized by criteria and indicators within different sustainability analyses.

In the case of freshwater abstraction, treatment, and distribution, the methods of LCA and LCC were used to assess environmental and economic performances of alternative technology options as well as the old system (before the IWRM activities) and the theoretical new system (after implementing selected technology options within the IWRM). Based on this, relevant input for the 
Table 7 Advantages and disadvantages of using a ranking and an expressing the overall results

\begin{tabular}{|c|c|c|c|}
\hline $\mathrm{Nr}$. & Approaches & Advantages & Disadvantages \\
\hline 1 & $\begin{array}{l}\text { Ranking/prioritization of the indicators by all } \\
\text { stakeholder groups to reveal the degree of } \\
\text { importance of the indicators, without weighting of } \\
\text { stakeholders' importance }\end{array}$ & $\begin{array}{l}\text { Simple method } \\
\text { Accommodate the } \\
\text { interests of all } \\
\text { stakeholders in an } \\
\text { equal way }\end{array}$ & $\begin{array}{l}\text { Disallow precise comparison, compared to weighting of } \\
\text { stakeholder importance }\end{array}$ \\
\hline 2 & $\begin{array}{l}\text { Expressing overall results, without aggregating the } \\
\text { score of each system }\end{array}$ & $\begin{array}{l}\text { High transparency, } \\
\text { since the analysis is } \\
\text { comprehensible }\end{array}$ & $\begin{array}{l}\text { Since an aggregate score is not available, it becomes } \\
\text { difficult to make quick and easily communicable } \\
\text { decisions. If an aggregate score would be applied, } \\
\text { each indicator should be weighted considering } \\
\text { stakeholder importance, not just ranked, for example } \\
\text { using analytical hierarchy process (AHP). But such a } \\
\text { weighting or AHP that would imply an assessment of } \\
\text { knowledge and values between stakeholders might } \\
\text { lead to uncertain and arbitrary results }\end{array}$ \\
\hline
\end{tabular}

IWRM project was provided, e.g., for decision support. Moreover, they provided relevant information which can be used in potential future technology assessments in contexts similar to the IWRM project in Indonesia.

The knowledge about sustainability in the sanitation sector could be transferred into operable planning steps by comparing the existing situation with the intended sanitation situation in the region, by means of a distance-to-target analysis (second step of SusTA, see Table 1) using baseline and target values for relevant indicators, such as health status, sanitation coverage, etc (for further details see Nayono 2014). A multi-dimensional sustainability technology assessment (combination of multi-criteria analysis and systems analysis) adopted in SusTA could provide a comprehensive picture of a technology by integrating several assessment methods. The thirteen technology assessment indicators (Fig. 4) describe the minimum requirements to assess the sustainability performance of a sanitation system in a region of a developing country and thus can help to improve the sanitation situation. To enhance the natural and the socio-technical water system of a region and to reduce vulnerabilities, the involvement of different stakeholder groups in the planning steps is required. The lessons learned from the case study revealed that participation does not always require to involve all stakeholders in all steps of the planning process. It is recommended to involve only relevant stakeholders (depending on the required competencies, existing interests and influences) and to ensure appropriate participation procedures.

The options to do analysis using a ranking of indicators without weighting the relative importance of stakeholders and expressing the overall result in a rose-chart diagram are more appropriate for the users, particularly the villagers. These options respectively show advantages and disadvantages as depicted in Table 7.
In this respect, further research should be conducted to develop relatively simple approaches that are still accurate and appropriate for non-expert users.

For applying the LCA/LCC and SuSTA methods within the IWRM project, the main practical challenge was the availability of data in sufficient quantity and quality. As some of the alternative technology options were still in the planning phase when the studies started, specific or regional data were not always available. Moreover, data were incomplete or partly contradictory. In these cases, literature data were used, assumptions were made, and sensitivity analyses were conducted assessing the influence of varying parameters on the LCA and LCC results.

In conducting sustainability assessment, targets, scopes, and assumptions might vary in different cases, which might make it difficult to compare them. This problem can be overcome by developing comprehensive indicator fulfillment conditions based on various empirical data from developing countries. These fulfillment conditions are useful to achieve common values on what is considered as less or more sustainable.

Freshwater and waste water systems in developing countries often are not functioning at all and thus do not serve the purpose they have been constructed for. Translated into the language of the Brundt and report, they do not meet the needs of the present generation. While technology sustainability assessments often do not address this functionality issue suitably, this should be given more emphasis in the water and sanitation sector. Because of this, criteria and indicators have to be developed describing the necessary conditions of technologies to come into a stable functioning. The technology diffusion process into the society (which might take longer than the technology innovation process) should be considered when developing such criteria and indicators. 
While, as mentioned above, target $7 \mathrm{c}$, related to drinking water and sanitation, of the Millennium Development Goals was "hidden" in the general Goal 7 "ensure environmental sustainability" (United Nations 2000), the topic of "clean water and sanitation" emerged to one of the 17 main goals of the actual sustainable development goals (SDG) of the United Nations, adopted on September 25, 2015 at the United Nations Summit on the post-2015 development agenda (United Nations 2015). As the global economy, the society and the natural environment are dynamic and also subject to constant change; IWRM approaches, therefore, need to be responsive to change and be capable of adapting to new economic, social, and environmental conditions and to changing human values. That is why within Goal 6 of the SDG (clean water and sanitation) one of eight targets aims at implementing integrated water resources management at all levels by 2030, including the approach of transboundary cooperation as far as appropriate.

Open Access This article is distributed under the terms of the Creative Commons Attribution 4.0 International License (http:// creativecommons.org/licenses/by/4.0/), which permits unrestricted use, distribution, and reproduction in any medium, provided you give appropriate credit to the original author(s) and the source, provide a link to the Creative Commons license, and indicate if changes were made.

\section{References}

Ambrose M, Burn S, DeSilva D, Rahilly M (2008) Life cycle analysis of water networks. Plastics Pipe XIV: Plastics Pipes Conferences Association, Budapest

Barriosa R, Siebela M, van der Helmb A, Bosklopperd K, Gijzena H (2008) Environmental and financial life cycle impact assessment of drinking water production at waternet. J Clean Prod 16(4):471-476

Brikké F, Bredero M (2003) Linking technology choice with operation and maintenance in the context of community water supply and sanitation: a reference document for planners and project staff. World Health Organization and IRC Water and Sanitation Centre, Geneva. ISBN: 9241562153

CML (2001) CML guide_part 2b: operational annex. http://media. leidenuniv.nl/legacy/new-dutch-lca-guide-part-2b.pdf. Accessed 22 Sept 2010

Eawag (Swiss Federal Institute of Aquatic Science and Technology) (2005) Household-centred environmental sanitation. Implementing the Bellagio principles in urban environmental sanitation provisional guideline. ISBN 3-906484-35-1

Ecoinvent (2007) Ecoinvent 2.0, Swiss Centre for Life Cycle Inventories. http://www.ecoinvent.ch/. Accessed $20 \mathrm{Feb} 2011$

Eiche E, Hochschild M, Hartmann A, Neumann T (2013) Abschlussbericht des Teilprojekts 3 „Geowissenschaftliche Exploration von unterirdischen Karstfließgewässern und Nutzung von mineralischen Ressourcen zur Trinkwasseraufbereitung "zum Integrierten Wasserressourcen-Management (IWRM). Institute of Mineralogy and Geochemistry, Karlsruhe Institute for Technology, Indonesien (Unpublished)
Gajurel DR (2003) Evaluation of decentral physico-biological systems for pre-treatment of household wastewater and their potential for ecological sanitaiton. Dissertation, Institute for Wastewater Management and Water Protection, Hamburg University of Technology, Hamburg

Ghimire SR, Watkins DW, Li K (2012) Life cycle cost assessment of a rain water harvesting system for toilet flushing. Sci Tech Water Supply 12(3):309-320

GWP (2000) Global water partnership, technical advisory committee, TEC background paper no. 4: integrated water resources management. Global Water Partnership, Stockholm, p 22

Heckmann A (2011) Vulnerabilitätskartierung und Gefahrenabschätzung zum Schutz der Trinkwasser-versorgung in der Ländlichen Karstregion Gunung Sewu, Java, Indonesien. Diploma thesis, Fakultät für Chemie und Geowissenschaften Geographisches Institut, Ruprecht-Karls-Universität Heidelberg

Hunkeler D, Lichtenvort K, Rebitzer G, Ciroth A (2008) Environmental Life Cycle Costing. Taylor and Francis, CRC Press, Boca Raton, FL, USA

ISO14040 (2006a) Environmental Management - Life Cycle Assessment - Principles and framework. International Organization for Standardization, Geneva, Switzerland

ISO14044 (2006b) Environmental Management - Life Cycle Assessment - Principles and framework. International Organization for Standardization, Geneva, Switzerland

ITAS, KIT (Institute for Technology Assessment and Systems Analysis, Karlsruhe Institute of Technology) and Faculty of Geography, Gadjah Mada University (UGM) (2010) Survey on water and wastewater-related conditions in recharge area of Bribin, Gunung Kidul, Yogyakarta, Indonesia (unpublished)

IWRM (2011) "BMBF-Verbundprojekt IWRM Indonesien". http:// www.iwrm-indonesien. Accessed 30 Nov 2011

KEMENNEG PDT - State Ministry for Development of Disadvantaged Regions (2005) Decree of the Minister 001/KEP/M-PDT/I/ 2005. National Development Strategic for Disadvantaged Regions

Kopfmüller J, Brandl V, Jörissen J, Paetau M, Banse G, Coenen R, Grunwald A (2001) Nachhaltige entwicklung integrativ betrachtet. Konstitutive Elemente, Regeln, Indikatoren. Sigma, Berlin

Lassaux S, Renzoni R, Germain A (2007) Life cycle assessment of water from the pumping station to the wastewater treatment plant. Int J Life Cycle Assess 12(2):118-126

Lehmann A (2013) Lebenszyklusbasierte Nachhaltigkeitsanalyse von Technologien: Am Beispiel eines Projekts zum Integrierten Wasserressourcenmanagement. (Life cycle based sustainability assessment of technologies). Dissertation, Technische Universität Berlin

Lüthi C, Morel A, Tilley E, Ulrich L (2011) Community-led urban environmental sanitation planning: CLUES. Complete guidelines for decision-makers with 30 tools. Eawag Sandec/WSSCC/ UN-HABITAT

McConville J (2010) Unpacking sanitation planning. Comparing theory and practice. Dissertation. Department of Architecture, Chalmers University of Technology, Gothenburg. ISBN 978-917385-483-2

Nayono S (2014) Development of a sustainability-based sanitation planning tool (SuSTA) for developing countries. Case study: integrated water resources management (IWRM) project, Gunung Kidul, Indonesia. Dissertation, Faculty of Engineering, Bauhaus-Universität Weimar, Germany. http://e-pub.uniweimar.de/opus4/frontdoor/index/index/docId/2222. Accessed 21 Dec 2015

Nestmann F, Oberle P, Ikhwan M, Lux T, Scholz U (2009) Bewirtschaftung unterirdischer Fließgewässer in KarstgebietenPilotstudie auf Java, Indonesien. WasserWirtschaft 7-8:12-18 
Nestmann F, Oberle P, Ikhwan M, Stoffel D (2010) Adaptive water resources management under extreme climatic and hydrogeological conditions: interdisciplinary research activities in Karst Regios of South East Asia. In: Proceedings of the IWRM Karlsruhe 2010, Karlsruhe, pp 300-307

Oberle P, Ikhwan M, Stoffel D Nestmann F (2016) Adapted hydropower-driven water supply system: assessment of an underground application in an Indonesian karst area. J Appl Water Sci (this special issue)

Saaty TL (1980) The analytic hierarchy process. McGraw-Hill international, New York

Swarr T, Hunkeler D, Klöpffer W, Pesonen H-L, Ciroth A, Brent AC, Pagan, R (2011) Environmental life cycle costing: a code of practice. Int J Life Cycle Assess. 13(2):89-95

Tchobanoglous G, Burton FL, Stensel HD, Metcalf and Eddy, Inc (2003) Wastewater engineering: treatment and reuse. 4th edn, McGraw-Hill, New York, USA
Tilley E, Lüthi C, Morel A, Zurbrügg C, Schertenleib R (2008) Compendium of sanitation systems and technologies. Swiss Federal Institute of Aquatic Science and Technology (Eawag), Dübendorf. ISBN 978-3-906484-44-0

United Nations (2000) Millenium development goals and beyond 2015-goal 7. http://www.un.org/millenniumgoals/environ. shtml. Accessed 25 Nov 2015

United Nations (2015) Sustainable development goals. http://www. un.org/sustainabledevelopment/sustainable-development-goals/. Accessed 25 Nov 2015

US AfID (2003) US Agency for International Development 2003. Online at cited in: Cardwell HE, Cole RA, Cartwright LA, Martin LA (2006) Integrated water resources management: definitions and conceptual musings. J Contemp Water Res Educ 135:8-18 